\title{
Kerendahhatian dan Pemaafan pada Mahasiswa
}

\author{
Yogi Kusprayogi, ${ }^{1}$ Fuad Nashori ${ }^{2}$ \\ Universitas Islam Indonesia (UII), Yogyakarta
}

\begin{abstract}
This study aims to determine the correlation between humility and forgiveness in students. Respondents in this research are 252 students majoring in Psychology, Faculty of Psychology and Social and Cultural Sciences, Islamic University of Indonesia, with ages range from 17 to 24 years old. The hypothesis put forward by researchers is that there is positive correlation between the variables of humility and forgiveness in students. The research data in this study were analyzed using analytical techniques and product moment correlation from Karl Pearson; that is used to examine the relation between variables. The results showed that there is a positive correlation between humility and forgiveness $(\mathrm{r}=0$. 508 and $\mathrm{p}<0.05)$ with the contribution of humility on the forgiveness of $25.8 \%$. Other results showed that there are different aspects of humility that contribute to forgiveness, in terms of demographic variables of age and gender.
\end{abstract}

Keywords: forgiveness; humility; students

\begin{abstract}
Abstrak: Penelitian ini bertujuan untuk mengetahui hubungan kerendahhatian dan pemaafan pada mahasiswa. Responden dalam penelitian ini adalah 252 mahasiswa jurusan psikologi, Fakultas Psikologi dan Ilmu Sosial Budaya Universitas Islam Indonesia, dengan rentang usia 17-24 tahun. Hipotesis yang diajukan peneliti adalah adanya hubungan positif antara variabel kerendahhatian dan pemaafan pada mahasiswa. Data yang diperoleh dalam penelitian dianalisis dengan menggunakan teknik analisis dan korelasi product moment dari Karl Pearson yang digunakan untuk melihat hubungan antar variabel. Hasil penelitian menunjukkan bahwa ada korelasi positif antara kerendahhatian dan pemaafan $(r=0,508$ dan $\mathrm{p}<0,05)$ dengan kontribusi variabel kerendahhatian pada pemaafan sebesar $25,8 \%$. Hasil lainnya menunjukkan ada perbedaan aspek kerendahhatian yang berkontribusi pada pemaafan ditinjau dari variabel demografi usia dan jenis kelamin.
\end{abstract}

Kata kunci: kerendahhatian; mahasiswa; pemaafan

Interaksi sosial merupakan tahapan di mana manusia memulai hubungan antara satu dengan yang lainnya. Manusia berinteraksi sosial untuk dapat saling mengenal, memahami dan bekerjasama satu sama lain. Interaksi sosial juga mengantarkan manusia pada kondisi bahagia, senang, bermakna, atau marah, sedih, tersakiti bahkan hingga konflik. Di Indonesia

Korespondensi mengenai isi artikel ini dapat dilakukan melalui email: ${ }^{1}$ kusprayogi@gmail.com 2fuadnashori@yahoo.com 


\section{Kerendahhatian dan Pemaafan pada Mahasiswa}

saat ini mudah ditemukan berbagai konflik sosial yang terjadi di masyarakat, mulai dari konflik perorangan hingga konflik kelompok yang melibatkan masyarakat umum. Konflik yang tidak sehat tentunya menimbulkan kerugian fisik, psikis, sosial, dan finansial. Akibatnya, konflik menjadikan individu tidak mampu mencapai kesejahteraan hidup dengan baik, dikarenakan kondisi tidak nyaman yang ditimbulkan dari konflik yang sedang dialami oleh individu.

Banyak konflik terjadi pada perorangan terutama mahasiswa. Hal tersebut dikarenakan usia mahasiswa masih tergolong remaja yang identik dengan masalah. Menurut Hall (dalam Santrock, 2002) masa remaja adalah masa topan dan badai (strom and stress) karena pada masa ini remaja berada pada tahap kebebasan menentukan nasib sendiri. Pikiran, perasaan dan tindakan pada remaja berisi tentang kesombongan atau kerendah hatian, kebaikan atau godaan keburukan, serta kegembiraan atau kesedihan (Hall dalam Santrock, 2002). Menurut Rostiana (1999), jika seseorang kurang terampil menjalin hubungan sosial maka konflik interpersonal akan mudah terjadi pada individu tersebut. Konflik interpersonal dirasa memiliki dampak paling signifikan bagi individu. Dampak buruk yang diterima individu dalam sebuah konflik interpersonal antara lain trauma, marah, benci, dendam, bersikap pasif, hilangnya kepercayaan dan semangat, tidak ingin bertemu pelaku (menghindar), cemas, khawatir, takut, stres, depresi dan sejenisnya (Nashori, Iskandar, Setiono, \& Siswandi, 2011). Segala hal yang berhubungan dengan konflik terkait siapa, di mana, kapan, dan bagaimana ternyata memberikan dampak yang cukup signifikan terhadap perkembangan psikologis individu.

Berdasarkan penelitian Arif (2013) konflik interpersonal remaja adalah konflik yang sering dialami remaja dengan teman bermainnya. Remaja menilai lingkungan dan temannya berdasarkan keserasian atau kesamaan yang dimilikinya. Jika terdapat perbedaan, maka memicu timbulnya pengabaian dan kurangnya penerimaan. Selanjutnya, beberapa kesalahan yang dilakukan oleh individu seperti ketidaksetiaan, pengkhianatan, kebrutalan, dan agresivitas dapat memberikan luka dan korban jiwa yang sulit untuk dimaafkan. Hal ini menimbulkan frustrasi dikarenakan rasa kecewa yang kemudian dapat menyebabkan berbagai dampak negatif, salah satunya berperilaku agresif ingin membalas (Arif, 2013).

Berdasarkan data hasil wawancara dengan beberapa mahasiswa Fakultas Psikologi diperoleh kasus-kasus sebagai berikut:

"Peristiwa menyakitkan itu terjadi sudah cukup lama, itu terjadi karena ada trigger yang memicu setiap perlakuan. Perlakuan itu membuat saya dirugikan hingga membuat saya ingin 


\section{Yogi Kusprayogi, Fuad Nashori}

bunuh diri, ingin rasanya mati. Secara emosi saya merasakan marah benci, dan dendam campur semua menjadi satu, emosi saya tidak bisa saya kontrol. Peristiwa ini menjadi sangat menyakitkan karena saya sudah terlalu percaya pada pelaku. Awalnya saya percaya bahwa semua orang baik, pada akhirnya saya dikecewakan dan hingga kini saya tidak mudah percaya lagi pada orang lain. Rasa itu masih saya rasakan hingga detik ini. Saya merasa tidak nyaman dan memilih menghindar daripada harus bertemu dengan orang itu. Rasa percaya itu tidak mudah dibangun, dan menurut saya akan sangat lama, kalaupun memaafkan tidak akan bisa seperti dulu. Saya sudah mencoba mempertimbangkan dan memikirkan semua kebaikan dia, namun satu keburukan yang dia lakukan telah menghapus semua kebaikan dia di masa lalu. Kini saya tidak akan mudah percaya pada oranglain. Pada pelaku, saya lebih milih mencoba tidak peduli dengan apa yang dilakukannya saat ini. Untuk balas dendam padanya, jika ada kesempatan saya ingin membalas dengan merusak hidupnya. Hingga saat ini saya tidak bisa menerima rekonsiliasi. Tidak ada keinginan untuk menjalin hubungan kembali dengan pelaku. Biarkan saja seperti ini." (Mahasiswa X, pria, 23 Tahun).

"Saya sungguh marah pada diri saya, saya memiliki situasi di mana saya tidak bisa memaafkan situasi itu. Situasi itu membuat saya begitu trauma. Padahal itu sudah terjadi 10 tahun yang lalu. Sesekali saat ini kadang saya tiba-tiba mengingatnya dan hal itu menimbulkan perasaan sangat tidak nyaman bagi saya. Saya merasa marah, merasa benci, dan akhirnya saya merasa stres sendiri. Jika sudah demikian saya kurang dapat mengontrol diri saya. Alternatif yang saya lakukkan saat ini adalah menghadap Allah dan muhasabah untuk mencertikan apa yang terjadi. Saya sadar jika saya sulit untuk memaafkan, dan saya juga sadar efek ini sungguh buruk bagi saya. Namun saya memang belum bisa menerimanya dan melepaskan perasaan ini dari diri saya. Kadang saya takut, cemas, namun saya mencoba untuk melewatinya. Untuk saat ini biarkan dulu seperti ini." (Mahasiswi Y, wanita, 23 Tahun).

Kasus lain yang dimuat berdasarkan data dari media massa di Indonesia, sebuah berita dimuat dalam merdeka.com menyatakan bahwa terjadi pembunuhan pada korban (AS) berusia (19) tahun (perempuan) yang dilakukan oleh teman korban sendiri. Tersangka berusia (19) tahun (laki-laki) melakukan pembunuhan dibantu teman perempuannya yang berusia (18) tahun. Menurut keterangan tersangka, tersangka membunuh korban (AS) karena sakit hati dan merasa dikhianati http://www.merdeka.com/peristiwa/ini-motifpembunuhan-ade-sara-oleh-sepasang-kekasih.htm, 07 Maret 2015). Dua kasus di atas menunjukkan jika konflik yang dialami masing-masing individu baik dengan pelaku, diri sendiri, peristiwa dan situasi memberikan dampak secara emosi yang signifikan.

Dari temuan lapangan menunjukkan jika kegagalan interaksi sosial yang berdampak pada sakit hati, marah, dan dendam dapat menimbulkan tindak kekerasan bahkan berujung pada kematian. Burney dan Kromrey (2001) mengemukakan perlu adanya strategi manajemen kemarahan yang baik dan belajar mencari solusi positif sebagai alternatif bagi remaja untuk menghadapi suatu masalah. Hasil penelitian menunjukkan individu yang dapat memaafkan mengalami penurunan kemarahan, kecemasan dan depresi akibat kekerasan di 


\section{Kerendahhatian dan Pemaafan pada Mahasiswa}

masa kecil secara signifikan (Snyder \& Heinze, 2005). Selain itu menurut Worthington dan Scherer (2004) menyatakan bahwa pemaafan merupakan strategi emotion focused coping untuk meredakan stres, kesehatan yang baik, dukungan sosial, kualitas hubungan dan agama. Perilaku memaafkan dapat digunakan oleh remaja untuk bisa melepaskan semua beban penderitaan seperti stres, menyimpan dendam, beban pikiran dan perasaan sakit. Selesainya suatu konflik ditandai dengan adanya saling menerima dan memaafkan baik pada peristiwa, pelaku dan kondisi.

McCullough, Rachal, Sandage, Everett, Wortington, Brown, dan Hight (1998) mengemukakan bahwa pemaafan adalah seperangkat motivasi untuk mengubah seseorang untuk tidak membalas dendam dan meredakan dorongan untuk konsiliasi dengan pihak yang menyakiti. Nashori (2014) mendefinisikan pemaafan dengan kesediaan untuk meninggalkan hal-hal tidak menyenangkan yang bersumber dari hubungan interpersonal dengan menumbuhkan dan mengembangkan perasaan, pikiran dan hubungan yang lebih positif dengan orang yang telah melakukan perbuatan tidak menyenangkan.

Pemaafan sebagai kesediaan seseorang untuk meninggalkan kemarahan, penilaian negatif, dan perilaku acuh tidak acuh terhadap orang lain yang telah menyakitinya dengan tidak adil. Di sisi lain dengan tidak menyangkal rasa sakit itu sendiri tetapi dengan menimbulkan rasa kasihan, iba dan cinta pada pihak yang menyakiti (Enright, 2001). Dari pengertian tersebut dapat disimpulkan bahwa pemaafan merupakan kemampuan seseorang untuk mengubah perasaan negatif atau tidak menyenangkan yang dirasakanakibat pelaku, tindakan, peristiwa dan situasi yang dialaminya menjadi perasaan positif dengan menerima dan mengambangkan menjadi rasa kasih, iba dan cinta.

Penelitian lain yang dilakukan Luskin (Nashori, 2014) menyatakan bahwa individu yang memaafkan akan semakin jarang terlibat konflik. Oleh karena itu pemaafan merupakan salah satu cara dalam mencegah terjadinya konflik, pemaafan memberikan implikasi yang besar dalam hubungan jangka pendek dan jangka panjang (Fincham, Beach, \& Davila, 2004). Hal tersebut menerangkan bahwa memaafkan merupakan salah satu metode resolusi konflik yang efektif untuk menyelesaikan konflik secara beradab, baik konflik kelompok maupun interpersonal.

Bahkan Islam secara tegas menganjurkan pemaafan pada pemeluk ajaran agamanya. Seperti firman Allah dalam surah Ali-Imran, 159:

"Maka disebabkan rahmat Allah kamu berlaku lemah lembut terhadap mereka. Sekiranya kamu bersikap keras lagi berhati kasar, tentulah mereka menjauhkan diri 


\section{Yogi Kusprayogi, Fuad Nashori}

dari sekelilingmu. Maka maafkanlah mereka, mohonkanlah ampunan bagi mereka, dan bermusyawarahlah dengan mereka dalam urusan itu. Kemudian apabila kamu telah membulatkan tekad, maka bertawakallah kepada Allah. Sesungguhnya Allah menyukai orang-orang yang bertawakal kepadanya"

Demikian juga dalam surah al- Syura, 40:

“Dan balasan suatu kejahatan adalah kejahatan yang serupa, maka barang siapa memaafkan dan berbuat baik maka pahalanya atas tanggungan Allah. sesungguhnya Dia tidak menyukai orang-orang zalim. "

Memaafkan menjadi hal yang sangat penting, karena jika individu tidak memaafkan akan memberikan dampak negatif bagi individu. Beberapa dampak negatif yang bisa dialami individu jika tidak memaafkan adalah emosi negatif yang memiliki efek negatif jangka panjang pada kesehatan, terutama jantung Brosschot \& Thayer (2003), meningkatkan tekanan darah Glynn, Christenfeld, \& Gerin (2002), menimbulkan gangguan kecemasan (Thayer \& Lane, 2000). Perasaan marah yang dibiarkan akan memicu reaksi emosi yang akan meninggalkan luka dan permusuhan yang berdampak pada perilaku, kepercayaan, penilaian yang buruk dan pada akhirnya memicu gejala frustrasi, penganiayaan, dan provokasi (Smith, 1992). Menurut Gani (2011), tidak memaafkan berdampak memiliki gejala tekanan darah tinggi, stres, kemarahan mudah terpicu, tekanan jantung meninggi, menunjukkan gejala depresi, menunjukkan gejala kecemasan, merasa nyeri akut pada tubuh, hubungan dengan orang lain kurang akrab, sukar menjalin persahabatan, merasa diri hampa, dan tendensi pelarian pada minuman beralkohol dan obat-obatan. Begitu banyak dampak buruk jika tidak memaafkan. Oleh karenanya, memaafkan merupakan pola dan sikap positif untuk kesejahteraan yang baik bagi individu.

Menurut Nashori (2014) pemaafan dibagi atas tiga dimensi yaitu (1) Dimensi Emosi. Beberapa indikator pemaafan dari dimensi emosi adalah (a) meninggalkan perasaan marah, benci, sakit hati. (b) Mampu mengontrol emosi saat diperlakukan tak menyenangkan. (c) Merasa iba dan kasih sayang terhadap pelaku. (d) Merasa nyaman ketika berinteraksi dengan pelaku. (2) Dimensi Kognisi, beberapa indikator pemaafan dari dimensi kognisi adalah (a) meninggalkan penilaian negatif terhadap pelaku. (b) Punya penjelasan nalar atas perlakuan yang menyakitkan. (c) Memiliki pandangan yang berimbang terhadap pelaku, (3) Dimensi Interpersonal, beberapa indikator pemaafan dari dimensi Interpersonal adalah (a) meninggalkan perilaku atau perkataan yang menyakitkan. (b) Meninggalkan keinginan balas dendam. (c) Meninggalkan perilaku acuh tak acuh. (d) Meninggalkan perilaku menghindar. (e) Meningkatkan upaya konsiliasi/rekonsiliasi hubungan. (f) Motivasi kebaikan atau kemurahan hati. (g) Musyawarah dengan pihak yang pernah menjadi pelaku. 


\section{Kerendahhatian dan Pemaafan pada Mahasiswa}

Beberapa faktor yang memengaruhi pemaafan menurut McCullough, Rachal, Sandage, Everett, Wortington, Brown, dan Hight (1998) dapat dikelompokkan menjadi empat kategori konseptual, antara lain (a) Sosial-kognitif, (b) Tingkat kelukaan atau serangan, (c) Hubungan Interpersonal, (d) Kepribadian. Bagi mahasiswa, menejemen diri sangatlah dibutuhkan, kemampuan internal individu merupakan salah satu faktor paling efektif untuk meningkatkan pemaafan. Kepribadian merupakan faktor internal yang dimiliki setiap individu (Nashori, 2014). McCullough, dkk, (1998) menyatakan bahwa kepribadian individu yang ekstrovert akan lebih mudah memaafkan karena individu berkepribadian ekstrovert menunjukkan karakter seperti berjiwa sosial, terbuka, asertif, hangat kooperatif, tidak mementingkan diri sendiri, jujur, sopan, fleksibel, empatik, dan bersahabat. Sedangkan kepribadian introvert menunjukkan kecenderungan seseorang bersikap tertutup, tidak asertif, suka menyembunyikan perasaan, cenderung terbenam dalam sensasi jiwanya sendiri, serta memandang dunia sebagai sesuatu yang tidak menarik

Teori McCullough, dkk (1998) menyatakan kepribadian merupakan faktor pembentuk pemaafan. Dalam hal ini peneliti mengacu pada penelitian Ashton dan Lee (2007) yang menyatakan ada aspek kepribadian dalam struktur kepribadian HEXACO yang memiliki sifat hampir sama dengan tipe ekstrovert. Ashton dan Lee (2007) menyatakan bahwa HonestHumility adalah salah satu aspek kepribadian dalam struktur kepribadian HEXACO personality yang memiliki sifat tulus, jujur, setia/loyal, sederhana, berpikiran adil dan tulus, sikap tersebut berlawanan dengan keserakahan, penghindaran, licik, sok, munafik, sombong, dan angkuh.

Khalid (2006) mengatakan kerendahhatian mempunyai tiga makna, yaitu menerima kebenaran yang datangnya dari siapa saja dan mampu menjalin interaksi dengan semua manusia dan Merendahkan diri di hadapan Allah. Templeton (1997) menyampaikan bahwa kerendahhatian merupakan kebalikan dari arogansi. Kerendahan hati yang sejati mempromosikan keterbukaan untuk belajar dari orang lain dan membangun komunitas. Sedangkan Elliot (2010) menyatakan humility (kerendahhatian) adalah kemampuan untuk mengakui kesalahan diri, ketidaksempurnaan, kesenjangan/keterbatasan diri dan keterbukaan untuk menerima ide-ide baru, informasi, dan saran. Dapat juga dikatakan sebagai penilaian yang akurat dari kemampuan seseorang dan prestasi dirinya.

Agama Islam menganjurkan pada pemeluknya untuk tawadhu (Kerendahhatian) dalam menjalin hubungan dengan Allah dan dengan sesama manusia. Kerendahhatian juga dicontohkan oleh Nabi Muhammad sebagai akhlaq mulia yang harus dimiliki oleh para 


\section{Yogi Kusprayogi, Fuad Nashori}

pemeluk islam. Seperti firman Allah dalam al-Qur'an, Allah berfirman dalam surah AlFurqan, 63 :

"Dan hamba-hamba Allah yang maha pengasih itu adalah orang-orang yang berjalan di bumi dengan rendah hati dan apabila orang bodoh (kafir) menyapa mereka (dengan kata-kata yang menghina), mereka megucapkan "salam".

Selain itu Nabi Muhammad juga pernah bersabda:

"tiada satu pun karunia yang diperoleh seseorang yang bersikap tawadhu kepada Allah kecuali Allah meninggikan derajatnya”(HR. Muslim no. 6535).

Elliot (2010) menyatakan kerendahhatian terbagi atas empat aspek sebagai berikut: (1) Openness, yaitu membuka diri pada segala hal yang bersifat positif tanpa mempertimbangkan siapa dan di mana diperoleh. (2) Self forgetfulness, yaitu merasa memiliki kekurangan dan kelemahan diri. (3) Modest self-assessment, yaitu penilaian diri yang sederhana tidak melebih-lebihkan tidak sombong dan berbesar diri. (4) Focus on others, yaitu memperhatikan orang lain memahami orang lain serta menghargai orang lain. Elliot (2010) menyatakan bahwa dalam sebuah hubungan interpersonal, Kerendahhatian dan empati merupakan cara yang baik untuk menyelesaikan konflik. Kerendahhatian dan empati mampu menjadikan masalah lebih mudah untuk difahami. Ketika masalah dapat dipahami maka akan mudah mendapatkan pengampunan (pemaafan) dan rekonsiliasi (perbaikan hubungan). Oleh karenanya peneliti ingin mengetahui hubungan positif kerendahhatian dan pemaafan, apakah seseorang yang rendah hati akan mudah memaafkan.

\section{Metode}

Variabel yang diteliti dalam penelitian ini adalah Pemaafan sebagai variabel tergantung dan kerendahhatian sebagai variabel bebasnya. Variabel pemaafan mengacu pada teori yang dikembangkan oleh Nashori (2014), Enright (2001), dan (McCullough et al., 1998). Sedangkan kerendahhatian mengacu pada teori yang dikembangkan oleh Elliot (2010) dan (Khalid, 2006).

Penelitian ini melibatkan 252 mahasiswa Prodi Psikologi Fakultas Psikologi dan Ilmu Sosial Budaya Universitas Islam Indonesia. Responden penelitian berjenis kelamin laki-laki dan perempuan, rentang usia remaja akhir hingga memasuki dewasa awal 17-24 tahun (Depkes, 2009). 


\section{Kerendahhatian dan Pemaafan pada Mahasiswa}

Metode penelitian ini menggunakan pendekatan kuantitatif. Metode pengumpulan data yang digunakan dalam bentuk skala alat ukur yaitu skala pemaafan dan skala kerendahhatian. Pemaafan akan diukur menggunakan Skala Pemaafan yang dikembangkan Nashori (2012), yang terdiri atas 3 dimensi, yaitu (1) Dimensi Emosi, (2) Dimensi Kognitif, dan (3) Dimensi Interpersonal. Cara mengukur pemaafan menggunakan skala pemaafan yang dikembangkan Nashori (2015) berdasarkan tiga dimensi pemaafan terdiri dari 14 item. Skor pemaafan diperoleh berdasarkan pengisian skala pemaafan oleh responden. Hasil skala pemaafa nmenunjukkan tingkat pemafaan pada responden sesuai skor yang diperoleh, jika semakin tinggi skor skala pemaafan yang diperoleh maka tingkat pemaafan yang dimiliki seseorang semakin tinggi. Begitu juga sebaliknya, jika semakin rendah skor skala pemaafan yang diperoleh maka tingkat pemaafan yang dimiliki seseorang semakin rendah.

Kerendahhatian akan diukur menggunkan skala kerendahhatian yang dikembangkan oleh Peneliti mengacu pada teori kerendahhatian yang dikembangkan Elliot (2010), 24 item skala kerendahhatian terdiri dari empat aspek yaitu Openness, Self-Forgetfulness, Modest SelfAssessment, dan Focus on Other. Selanjutnya peneliti memasukan konsep islam dalam skala kerendahhatian sesuai aspek "merendahkan diri pada Allah" sesuai pendapat yang dikemukakan oleh (Khalid, 2006). Hasil skala kerendahhatian menunjukkan tingkat kerendahhatian pada responden sesuai skor yang diperoleh, jika semakin tinggi skor skala kerendahatian yang diperoleh maka tingkat kerendahhatian yang dimiliki seseorang semakin tinggi. Begitu juga sebaliknya, jika semakin rendah skor skala kerendahhatian yang diperoleh maka tingkat kerendahhatian yang dimiliki seseorang semakin rendah.

Penelitian ini merupakan penelitian korelasional, yang membandingkan dua variabel untuk mengetahui hubungan diantara dua variabel tersebut. Uji hipotesis dalam penelitian ini menggunakan teknik analisis dan korelasi Product moment dari Pearson yang digunakan untuk melihat hubungan antara variabel pemaafan dan kerendahhatian. Dalam penelitian ini, analisis data yang dilakukan adalah: (a) Uji Normalitas, (b) Uji Linearitas, (c) Uji Hipotesis dan (d) Uji Regresi. Penelitian ini menggunakan teknik analisis data computer SPSS 17. 0 for windows untuk mengolah data penelitian yang telah diperoleh.

\section{Hasil}

\section{Deskripsi Responden Penelitian}

Gambaran mengenai responden penelitian berdasarkan data yang diperoleh adalah sebagai berikut: 


\section{Yogi Kusprayogi, Fuad Nashori}

Tabel 1.

Deskripsi responden penelitian berdasarkan usia

\begin{tabular}{ccc}
\hline Usia & $\mathbf{N}$ & Persentase (\%) \\
\hline 17 & 4 & 1.58 \\
18 & 52 & 20.63 \\
19 & 109 & 43.25 \\
20 & 47 & 18.65 \\
21 & 25 & 9.92 \\
22 & 9 & 3.57 \\
23 & 6 & 2.38 \\
\hline Total & $\mathbf{2 5 2}$ & $\mathbf{1 0 0}$ \\
\hline
\end{tabular}

Berdasarkan data pada Tabel 1 diketahui bahwa responden penelitian yang berusia 17 tahun sebanyak 4 orang dengan persentase $1,58 \%$, usia 18 tahun sebanyak 52 orang dengan persentase 20,63\%, usia 19 tahun sebanyak 109 orang dengan persentase 43, 25\%, usia 20 tahun sebanyak 47 orang dengan persentase 18,65\%, 21 tahun sebanyak 25 orang dengan persentase 9, 92\%, 22 tahun sebanyak 9 orang dengan persentase 3, 57\%, 23 tahun sebanyak 6 orang dengan persentase $2,3 \%$.

Tabel selanjutnya akan menjelaskan persentase responden penelitian dalam norma persentil untuk menentukan tinggi-rendahnya tingkat kerendahhatian dan pemaafan.

Tabel 2.

Norma hasil kategorisasi menurut skor presentil

\begin{tabular}{ccccc}
\hline \multirow{2}{*}{ Kategorisasi } & \multicolumn{2}{c}{ Kerendahhatian } & \multicolumn{2}{c}{ Pemaafan } \\
& F & $\%$ & F & $\%$ \\
\hline Sangat Rendah & 47 & 18.65 & 50 & 19.84 \\
Rendah & 42 & 16.66 & 36 & 14.28 \\
Sedang & 51 & 20.23 & 62 & 24.60 \\
Tinggi & 57 & 22.61 & 43 & 17.06 \\
Sangat Tinggi & 55 & 21.82 & 61 & 24.20 \\
\hline
\end{tabular}

Tabel 2 menunjukkan bahwa persentase kerendahhatian terbesar berada di kategori tinggi (57 responden) dan pemaafan terbesar berada dalam kategori sedang (62 responden).

Tabel 3 menjelaskan terkait hasil uji hipotesis dan sumbangan efektif berdasarkan uji statistik. Berdasarkan hasil analisis data, hipotesis diuji menggunakan uji korelasi product moment dari Pearson. Diperoleh koefisien korelasi r sebesar 0, 508 dengan p 0, $000(p<0,05)$. 
Tabel 3.

Hasil uji hipotesis

\begin{tabular}{ccccc}
\hline Variabel & $\mathbf{N}$ & $\mathbf{R}$ & $\mathbf{r}^{2}$ & $\mathbf{p}$ \\
\hline Kerendahhatian*Pemaafan & 0.252 & 0,508 & 0,258 & $0.000(\mathrm{p}<0.05)$ \\
\hline
\end{tabular}

Angka pada Tabel 3 menunjukkan adanya korelasi yang signifikan antara variabel kerendahhatian dan pemaafan pada mahasiswa, ditunjukkan dengan Nilai korelasi Pearson sebesar $p=0,000(p<0,05)$. Skor kerendahhatian memberikan sumbangan sebesar 0,258 atau $25 \%$ terhadap pemaafan. Hasil analisis tersebut menunjukkan hubung antara dua variabel berarah positif, sehingga hipotesis dalam penelitian ini "diterima".

Hasil analisis data selanjutnya pada tabel 4 merupakan uji regresi berdasrkan jenis kelamin laki-laki untuk mengetahui sumbangan aspek kerendahhatian pada pemaafan berdasarkan variabel demografi jenis kelamin. Tabel 4 menunjukkan perbedaan aspek kerendahhatian penentu pemaafan pada laki-laki. Laki-laki lebih didominasi oleh aspek kerendahhatian focus on other, dan modest self-assessment dengan kontribusi sebesar masingmasing $19 \%$ dan 6, 7\% pada variabel pemaafan.

Tabel 4.

Hasil uji regresi kontribusi aspek kerendahhatian berdasarkan jenis kelamin laki-laki

\begin{tabular}{cccccc}
\hline Model & $\mathbf{R}$ & $\mathbf{r}^{2}$ & $\mathbf{r}^{2}$ change & $\mathbf{P}$ & $\mathbf{N}$ \\
\hline 1 & 0,19 & 0,178 & 0,19 & 0,000 & \multirow{2}{*}{69} \\
2 & 0,507 & 0,235 & 0,067 & 0,000 & \\
\hline
\end{tabular}

a. Predictors: (Constant), FO

b. Predictors: (Constant), FO, MSA

Hasil analisis Tabel 5 merupakan uji sumbangan efektif berdasarkan jenis kelamin perempuan untuk mengetahui sumbangan aspek kerendahhatian pada pemaafan berdasarkan variabel demografi jenis kelamin. Menggunakan teknik analisis regresi diperoleh data sebagai berikut:

Tabel 5 .

Hasil uji regresi kontribusi aspek kerendahhatian berdasarkan jenis kelamin perempuan

\begin{tabular}{cccccc}
\hline Model & $\mathbf{R}$ & $\mathbf{r}^{2}$ & $\mathbf{r}^{2}$ change & $\mathbf{P}$ & $\mathbf{N}$ \\
\hline 1 & 0,254 & 0,250 & 0,254 & 0,000 & \multirow{2}{*}{183} \\
2 & 0,280 & 0,272 & 0,025 & 0,000 & \\
\hline
\end{tabular}

a. Predictors: (Constant), OP

b. Predictors: (Constant), OP, FO

PSIKOHUMANIORA: Jurnal Penelitian Psikologi - Volume 1 No. 1, November 2016 


\section{Yogi Kusprayogi, Fuad Nashori}

Tabel 5 menunjukkan perbedaan aspek kerendahhatian penentu pemaafan pada perempuan. Kerendahhatian pada perempuan lebih ditentukan dengan aspek openness, dan focus on other masing-masing memberikan kontribusi sebesar $25 \%$ dan 2, 5\% pada variabel pemaafan.

Hasil analisis pada Tabel 6 dan Tabel 7 adalah pengujian sumbangan efektif berdasarkan variable demografi usia responden penelitian, untuk mengetahui sumbangan aspek kerendahhatian pada pemaafan berdasarkan variabel demografi usia. Tabel 6 menunjukkan data analisis usia di bawah 19 tahun Menggunakan teknik analisis regresi diperoleh data sebagai berikut.

Tabel 6.

Hasil uji regresi kontribusi aspek kerendahhatian berdasarkan usia responden $\leq 19$ tahun

\begin{tabular}{cccccc}
\hline Model & $\mathbf{R}$ & $\mathbf{r}^{2}$ & $\mathbf{r}^{2}$ change & $\mathbf{P}$ & $\mathbf{N}$ \\
\hline 1 & 0,499 & 0,245 & 0,249 & 0,000 & \multirow{2}{*}{165} \\
2 & 0,520 & 0,261 & 0,021 & 0,000 & \\
\hline
\end{tabular}

a. Predictors: (Constant), OP

b. Predictors: (Constant), OP, FO

Data selanjutnya ditinjau dari demografi usia.

Tabel 7 menunjukkan data analisis usia di sama dengan dan di atas 19 tahun menggunakan teknik analisis regresi diperoleh data sebagai berikut:

Tabel 7.

Hasil uji regresi kontribusi aspek kerendahhatian berdasarkan usia responden $>19$ tahun

\begin{tabular}{cccccc}
\hline Model & $\mathbf{R}$ & $\mathbf{r}^{2}$ & $\mathbf{r}^{2}$ change & $\mathbf{P}$ & $\mathbf{N}$ \\
\hline 1 & 0,480 & 0,230 & 0,230 & 0,000 & \\
2 & 0,543 & 0,295 & 0,065 & 0,000 & \\
\hline
\end{tabular}

a. Predictors: (Constant), FO

b. Predictors: (Constant), FO, MSA

Tabel 7 menunjukkan perbedaan aspek kerendahhatian penentu pemaafan antara laki-laki dan perempuan. Responden dengan usia >19 tahun lebih didominasi oleh aspek kerendahhatian focus on other, dan modest self-assessment dengan kontribusi sebesar masingmasing $24 \%$ dan 2, $1 \%$ pada variabel pemaafan. Sedangkan responden dengan usia $\leq 19$ tahun lebih ditentukan dengan aspek openness, dan focus on other masing-masing memberikan kontribusi sebesar $23 \%$ dan 6, 5\% pada variabel pemaafan. 


\section{Kerendahhatian dan Pemaafan pada Mahasiswa}

\section{Diskusi}

Hasil yang diperoleh berdasarkan analisis data yang telah dilakukan adalah $r=0,508$ dan $\mathrm{p}=0,000(\mathrm{p}<0,01)$. Hal tersebut menunjukkan bahwa ada hubungan positif antara kerendahhatian dan pemaafan. Semakin rendah hati seseorang maka orang tersebut memiliki tingkat pemaafan yang tinggi. Sebaliknya, jika seseorang memiliki tingkat kerendahhatian yang rendah maka orang tersebut memiliki tingkat pemaafan yang rendah juga. Hasil ini sesuai dengan yang disampaikan oleh McCullough dkk (1998) menyatakan bahwa kepribadian individu dapat memengaruhi sikap mudah memaafkan pada seseorang. Karakter kepribadian ekstrovert berjiwa sosial, terbuka pada orang lain, jujur, sopan, fleksibel, empatik, dan bersahabat adalah tipe kepribadian yang mudah memaafkan. Hal tersebut sejalan dengna konsep kerendahhatian dalam penelitian Ashton dan Lee (2007) merupakan salah satu aspek dalam struktur kepribadian HEXACO yang memiliki sifat lebih kompleks dengan tipe ekstrovert. Kerendahhatian merupakan karakter pribadi yang tulus, jujur, setia/loyal, sederhana, berpikiran adil, berlawanan dengan licik, serakah, sok, munafik, dan sombong.

Khalid (2006) dalam sudut pandang Islam menyatakan kerendahhatian (tawadhu) merupakan akhlak mulia kepada Allah dan manusia dengan indikator taat dan merendahkan diri di hadapan Allah, terbuka terhadap kebaikan dan kebenaran, cinta dan kasih sayang pada sesama manusia tanpa membedakan status sosial, dan kerendahhatian adalah lawan dari sombong. Bahkan Khalid (2006) juga menyatakan jika seseorang tidak nyaman dengan dirinya akibat dari kedzoliman dan kekotoran hati maka segeralah orang tersebut mengubah kepribadiannya menjadi pribadi yang rendah hati (tawadhu). Alasannya karena kesombongan merupakan sifat tercela yang menjadikan manusia dimurkai Allah. "Barang siapa yang besikap tawadhu satu derajat, maka Allah akan mengangkatnya satu derajat, sampai ia mencapai ketinggian deraja yang paling tinggi. Dan barang siapa yang melakukan kesombongan kepada Allah satu derajat, maka Allah akan merendahkannya satu derajat sampai ia mencapai kerendahan derajat yang serendah-rendahnya" (HR. Ahmad:III/76, dalam Khalid, 2006).

Oleh karena itu tidak mengherankan seseorang yang pemaaf merupakan orang yang berkepribadian rendah hati (tawadhu). Islam telah mengajarkan pada pemeluknya untuk berakhlak rendah hati (tawadhu) hal ini bukannya tanpa alasan, melainkan untuk membentuk akhlaq mulia dan derajat terbaik bagi pemeluknya. Dampak positif berkasih sayang, lemah lembut, iba, empati, peduli dan memandang segala sesuatu secara berimbang adalah pemaafan (Nashori, 2014). Dengan pemaafan maka seseorang telah membangun hubungan yang sehat dengan orang lain Elliot (2010), tidak hanya sosial, maanfaat 


\section{Yogi Kusprayogi, Fuad Nashori}

pemaafan juga membangun kesehatan mental dan fisik untuk lebih baik (Worthington \& Scherer, 2004; Worthington, Witvliet, Pietrini, \& Miller, 2007).

Hasil penelitian ini juga mendukung penelitian (Çardak, 2013). Berdasarkan penelitian yang dilakukan Çardak (2013) tentang variabel yang sama yaitu hubungan kerendahhatian dan pemaaafan pada mahasiswa di Turki. Hasil penelitian Çardak (2013) menunjukkan adanya hubungan positif antara kedua variabel, setiap aspek kerendahhatian memiliki kotribusi signifkan terhadap variabel pemaafan. Hasil ini memberikan dukungan empirik bahwa kerendahhatian ternyata memiliki dampak yang signifikan terhadap pemaafan.

Berdasarkan data hasil penelitian, diketahui bahwa kerendahhatian memiliki kontribusi sebesar 25, 8\% terhadap variabel pemaafan. Angka kontribusi ini masuk dalam kategori large effect size Cohen (1992) yang artinya kerendahhatian memberikan pengaruh yang cukup signifikan terhadap pemaafan. Faktor lain masih memiliki kontribusi sekitar 74, 2\% yang memengaruhi pemaafan pada seseorang. Beberapa faktor-faktor tersebut adalah religiusitas, sosial kognitif, hubungan interpersonal, tingkat kelukaan, usia, jenis kelamin, dan pendidikan (Nashori, 2014).

Temuan lain menggunakan analisis regresi adalah kontribusi empat aspek kerendahhatian terhadap pemaafan. Empat aspek pemaafan masing-masing memberikan kontribusi berbeda-beda terhadap pemaafan. Kontribusi terbesar diberikan aspek openness sebesar 21, 6\% pada variabel pemaafan. Openness merupakan membuka diri pada segala hal yang bersifat positif tanpa mempertimbangkan siapa dan dari mana diperoleh. Terbukti orang yang terbuka terhadap berbagai hal baik atau positif dan mampu mengakui kekurangannya menjadi indikator pertama seseorang memiliki sikap pemaaf. Seperti halnya yang diungkapkan McCullough, dkk. (1998) bahwa individu yang berjiwa sosial, terbuka pada orang lain, jujur, fleksibel, empatik, dan bersahabat adalah tipe kepribadian yang mudah memaafkan.

Aspek kerendahhatian yang memberikan sumbangan terbesar kedua dan ketiga adalah focus on other $(3,4 \%)$ dan self-forgetfulness $(1,4 \%)$. Aspek focus on others adalah memperhatikan orang lain memahami orang lain serta menghargai orang lain dan aspek self forgetfulness yaitu merasa memliki kekurangan, dan intropeksi diri. Kedua aspek ini beririsan dengan dimensi pemaafan interpersonal dan kognisi yaitu tidak menghindar, acuh tak acuh, menghargai orang lain, dan meninggalkan penilaian negatif terhadap pelaku dalam menghadapi konflik (Nashori, 2014). 


\section{Kerendahhatian dan Pemaafan pada Mahasiswa}

Temuan menarik lainnya adalah kontribusi aspek kerendahhatian berdasarkan kelompok usia $\leq 19$ tahun dan usia $>19$ tahun. Hasilnya, kelompok usia $\leq 19$ memiliki kontribusi aspek kerendahhatian openness sebesar $24 \%$ dan focus on other sebesar 2, $1 \%$. Sedangkan kelompok usia > 19 tahun memiliki kontribusi aspek focus on other sebesar 23\% dan modest self assessment sebesar 6, 5\%. Hasil ini menjelaskan jika kelompok usia $\leq 19$ memiliki karakteristik terbuka terhadap kebenaran, berpikir positif, peduli pada orang lain dan menghargai orang lain, yang kemudian aspek ini signifikan dan besar kontribusinya pada pemaafan di kelompok usia $\leq 19$. Pada kelompok usia $>19$ tahun karakteristik yang lebih dominan adalah peduli dan menghargai orang lain sebagai sumbangan terbesar pada pemaafan, sisanya disumbang oleh karakteristik penilain diri yang sederhana. Sesuai pendapat Nashori (2014) menyatakan bahwa semakin dewasa seseorang maka akan meningkatkan kematangan emosi, kepedulian dan empati. Hal ini sejalan dengan hasil analisis data, semakin dewasa usia responden, maka aspek kerendahhatian yang dominan adalah focus on other yang menunjukkan sifat menghargai, peduli, dan modest self assessment yang menunjukkan penilaian diri yang sederhana dan mampu menilai secara berimbang yang sejalan dengan kematangan emosi dalam memandang berbagai hal.

Berdasarkan hasil penelitian, menunjukkan ada perbedaan karaktersitik kerendahhatian yang berkontribusi kepada pamaafan. Ditinjau berdasarkan jenis kelamin perempuan dan laki-laki memiliki kontribusi aspek kerendahhatian pada pemaafan yang berbeda. Perbedaan karakteristik pemaafan tentunya akan berdampak pada tingkat pemaafan pada individu. Hasil ini sesuai dengan penelitian Utami (Arif, 2013) menyatakan bahwa laki-laki lebih mudah memaafkan dibandingkan perempuan. Laki-laki lebih baik dalam mengendalikan diri dan menggunakan logika atau pikiran yang diyakini. Laki-laki lebih memilki pandangan berimbang dan pandangan pada hal-hal masa depan yang positif, sehingga lebih mudah memulai menumbuhkan kembali rasa kepercayaan terhadap pelaku. Sedangkan perempuan cenderung lebih sulit untuk memaafkan karena perempuan lebih memanfaakan perasaan sebagai sarana manipulasi untuk mengendalikan diri (Jie, Tingting, Shijin, Lulu, \& Feng, 2011). Penelitian lain yang mendukungn hasil ini adalah penelitian Ghuzairoh (2015) yang meneliti tentang pemaafan ditinjau dari jenis kelamin pada budaya jawa. Hasilnya laki-laki lebih mudah memaafkan dibandingkan perempuan. Hal tersebut dikarenakan perempuan kurang bisa mengekspresikan perasaan yang yang ingin diungkapkan jika dibandingkan dengan laki-laki. Data ini juga mendukung pendapat Nashori (2014) menyatakan bahwa beberapa faktor penentu pemaafan merupakan jenis 


\section{Yogi Kusprayogi, Fuad Nashori}

kelamin dan usia. Dari sisi usia sesuai pendapat Nashori (2014) menyatakan bahwa semakin dewasa seseorang maka akan meningkatkan kematangan emosi, kepedulian dan empati.

Kerendahhatian memberikan kontribusi signifikan terhadap pemaafan. Jika seseorang dapat mengembangkan karakter kerendahhatian dalam dirinya, maka orang tersebut secara tidak langsung telah mengembangkan sikap pemaaf pada dirinya. Pemaafan yang dikembangkan akan berdampak pada keterampilan hubungan sosial, memiliki kesejahteraan diri yang baik (subjective well being dan psychlogical well being), dan kondisi fisik (kesehatan tubuh) yang lebih baik, serta kedamaian hati. Dengan memaafkan banyak manfaat yang dirasakan, hal ini sesuai janji Allah yang termaktub pada al-Qur'an Surah al-Syura 14 bahwa, Allah akan memberikan kebaikan (pahala) yang besar pada orang yang pemaaf.

Kelemahan dalam penelitian ini adalah peneliti tidak dapat mengontrol berbagai faktor yang memengaruhi pemaafan pada responden. Kelemahan penelitian kuantitatif korelasional adalah tidak mampu menjelaskan secara mendalam terkait konsep pemaafan pada masing-masing indivdu yang kemudian dikaitkan dengan kerendahhatian. Masingmasing responden memiliki tingkat sakit hati dan kelukaan yang berbeda satu dengan yang lain. Dampaknya pada pengisian skala pemaafan akan memberikan interpretasi kualitatif yang berbeda antara satu responden dengan responden yang lain. Maka hasil tinggi rendahnya skala pemaafan pada setiap responden belum tentu dapat digeneralisasikan pada populasi, mengingat tingkat peristiwa, situasi, pelaku dan tingkat kelukaan yang dialami setiap respoden tidaklah sama. Perlunya penambahan data kualitatif sebagai data tambahan yang membantu menjelaskan hasil penelitian secara mendalam tentang kerendahhatian dan pemaafan yang dimiliki oleh individu. Kelemahan yang kedua, peneliti menyadari bahwa pemaafan bukanlah merupakan hal yang sederhana untuk dilakukan. Memaafkan membutuhkan waktu dan proses yang berbeda-beda bagi setiap individu. Sehingga pengisian menggunakan skala pemaafan memiliki kelemahan dalam mengukur tingkat pemaafan yang sebenarnya, belum lagi adanya faking good dalam pengisian skala. Dalam penelitian selanjutnya perlu dilakukan menggunakan metode penelitian dan pemilihan responden dengan lebih baik dan spesifik.

\section{Simpulan}

Berdasarkan hasil analisis data dan pembahasan maka dapat disimpulkan bahwa tinggi rendahnya pemaafan dapat dijelaskan secara signifikan oleh kerendahhatian. Hasil analisis menjelaskan jika semakin tinggi kerendahhatian semakin tinggi pemaafan pada 


\section{Kerendahhatian dan Pemaafan pada Mahasiswa}

mahasiswa. Hasil ini menunjukkan jika kepribadian seseorang ternyata menentukan keputusan memaafkan dalam menghadapi berbagai situasi yang tidak menyenangkan. Mengembangkan karakter kerendahhatian berarti mengembangakan sikap pemaafan.

Saran

Mahasiswa perlu meningkatkan karakter rendah hati, sebab memiliki dampak baik bagi kehidupan, salah satunya untuk memaafkan berbagai hal. Setiap individu diharapkan mengembangkan sikap openness yaitu membuka diri pada kebenaran terhadap ide-ide baru, informasi, saran dan berbagai hal-hal positif. Selain openness, variabel yang memberikan dampak signifikan terbesar kedua adalah focus on other yang artinya menghargai, peduli dan empati pada orang lain. Aspek openness dan focus on other sangat bermanfaat untuk mengembangkan diri menjadi individu yang rendah hati dan pemaaf. Saran bagi peneliti selanjutnya, bagi penelitian selanjutnya yang akan mengangkat topik yang sama atau mengembangkan topik pemaafan atau kerendahhatian, bisa menambahkan atau mengaitkan dengan variabel yang lain semisal religiusitas, atau dengan metode penelitian yang berbeda seperti eksperimen pelatihan kerendahhatian atau metode lainnya, dan pengembangan alat ukur yang reliabilitas dan validitasnya lebih baik.

\section{Daftar Pustaka}

Arif, T. A. (2013). Komitmen dengan Pemaafan dalam hubungan persahabatan. Jurnal Online Psikologi, 1(2). Retrieved from http://ejournal. umm. ac. id/index. php/jop/ article/ view/1648

Ashton, M. C., \& Lee, K. (2007). Empirical, theoretical, and practical advantages of the HEXACO model of personality structure. Personality and Social Psychology Review, 11(2), 150-166.

Brosschot, J. F., \& Thayer, J. F. (2003). Heart rate response is longer after negative emotions than after positive emotions. International Journal of Psychophysiology, 50(3), 181-187. https://doi. org/10. 1016/S0167-8760(03)00146-6

Burney, D. M., \& Kromrey, J. (2001). Initial development and score validation of the adolescent anger rating scale. Educational and Psychological Measurement, 61(3), 446-460.

Çardak, M. (2013). The relationship between forgiveness and humility: A case study for university students - ProQuest. Educational Research and Reviews, 8(8), 425.

Cohen, S., Mermelstein, R., Kamarck, T., \& Hoberman, H. M. (1985). Measuring the functional components of social support, 73-94. https://doi. org/10. 1007/978-94009-5115-0_5 


\section{Yogi Kusprayogi, Fuad Nashori}

Depkes, R. I. (2009). Profil kesehatan Indonesia. Jakarta: Depkes RI.

Elliott, J. C. (2010). Humility: Development and analysis of a scale. University of Tennessee, Knoxville. Retrieved from http://trace. tennessee. edu/utk_graddiss/795

Enright, R. D. (2001). Forgiveness is a choice. Washington DC: American Psychological Association.

Fincham, F. D., Beach, S. R. H., \& Davila, J. (2004). Forgiveness and conflict resolution in marriage. Journal of Family Psychology, 18(1), 72-81. https://doi. org/10. 1037/08933200. 18. 1.72

Gani, H. A. (2011). Forgiveness therapy. Yogyakarta: Kanisius Yogyakarta.

Ghuzairoh, T. (2015). Perbedaan forgiveness ditinjau dari jenis kelamin pada Budaya Jawa. Fakultas Psikologi UIN Sunan Maulana Malik Ibrahim Malang.

Glynn, L. M., Christenfeld, N., \& Gerin, W. (2002). The role of rumination in recovery from reactivity: Cardiovascular consequences of emotional states. Psychosomatic Medicine, 64(5), 714-726.

Jie, W., Tingting, M., Shijin, S., Lulu, Y., \& Feng, W. (2011). Higher ruminative tendency of anger in trust-forgiveness young adults. Singapore: IACSIT Press.

Khalid, A. (2006). Semua akhlak nabi. Solo: Aqwam.

McCullough, M. E., Rachal, K. C., Sandage, S. J., Worthington, E. L., Jr., Brown, S. W., \& Hight, T. L. (1998). Interpersonal forgiving in close relationships: II. Theoretical elaboration and measurement. Journal of Personality and Social Psychology, 75(6), 15861603. https:// doi. org/10.1037/0022-3514. 75. 6. 1586

Nashori, F. (2012). Pemaafan pada Etnis Jawa. Unpad, Bandung.

Nashori, F. (2014). Psikologi pemaafan. Yogyakarta: Safiria Insania Press.

Nashori, F., Iskandar, T. Z., Setiono, K., \& Siswandi, A. G. P. (2011). Tema-tema pemaafan pada mahasiswa Yogyakarta. Yogyakarta: Fakultas Psikologi dan Ilmu Sosial Budaya UII.

Nashori, F., \& Wijaya, H. E. (2015). Pemaafan pada Etnis Minangkabau (Pengaruh religiositas dan keterikatan interpersonal melalui sifat kebersetujuan dan sifat neurotisisme terhadap pemaafan). Yogyakarta: Fakultas Psikologi dan Ilmu Sosial Budaya UII.

Rostiana. (1999). Diskripsi dan dinamika koflik pada boundary role person. Jurnal Ilmiah Arkhe, 4 (7).

Santrock, J. W. (2002a). Life span-development Edisi Kelima Jilid 2 (5th ed. ). Jakarta: Erlangga.

Smith, T. W. (1992). Hostility and health: Current status of a psychosomatic hypothesis. Health Psychology, 11(3), 139-150. https:// doi. org/10. 1037/0278-6133. 11. 3. 139

Snyder, C. R., \& Heinze, L. S. (2005). Forgiveness as a mediator of the relationship between PTSD and hostility in survivors of childhood abuse. Cognition \& Emotion, 19(3), 413431. https://doi. org/10. 1080/02699930441000175

Syamil Quran. (2009). al-Qur'an dan terjemahan. Bandung: Sygma. 


\section{Kerendahhatian dan Pemaafan pada Mahasiswa}

Templeton, J. M. (1997). Worldwide laws of life: Two hundred eternal spiritual principles. Tice: Templeton Press.

Thayer, J. F., \& Lane, R. D. (2000). A model of neurovisceral integration in emotion regulation and dysregulation. Journal of Affective Disorders, 61(3), 201-216. https://doi. org/10. 1016/S0165-0327(00)00338-4

Worthington, E. L., \& Scherer, M. (2004). Forgiveness is an emotion-focused coping strategy that can reduce health risks and promote health resilience: theory, review, and hypotheses. Psychology \& Health, 19(3), 385-405. https://doi. org/10. 1080/ 0887044042000196674

Worthington, E. L., Witvliet, C. V. O., Pietrini, P., \& Miller, A. J. (2007). Forgiveness, health, and well-being: A review of evidence for emotional versus decisional forgiveness, dispositional forgivingness, and reduced unforgiveness. Journal of Behavioral Medicine, 30(4), 291-302. https://doi. org/10. 1007/s10865-007-9105-8

http:/ / www.merdeka.com/peristiwa/ini-motif-pembunuhan-ade-sara-oleh-sepasangkekasih. htm. (diakeses pada 07 Maret 2015). 